
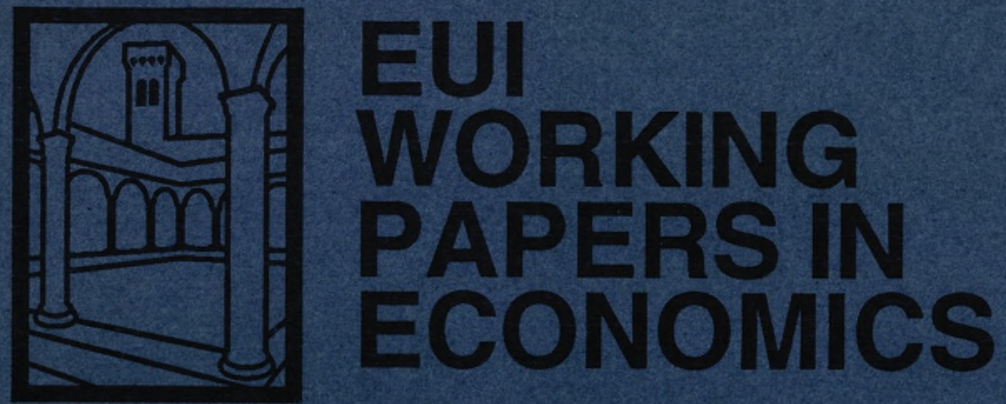

EUI Working Paper ECO No. 94/11

How Does the Hungarian

Unemployment Insurance System Really Work?

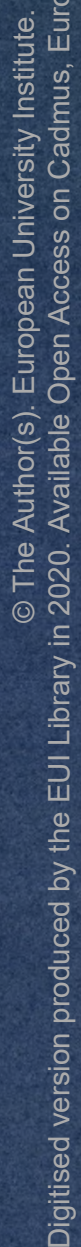

European University Institute, Florence 


\section{European University Library}

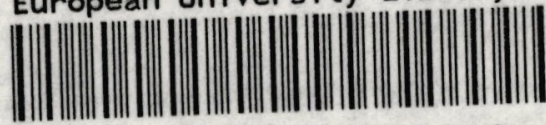

30001001552126

\section{Please note}

As from January 1990 the EUI Working Paper Series is divided into six sub-series, each sub-series is numbered individually (e.g. EUI Working Paper ECO No. 90/1). 
EUROPEAN UNIVERSITY INSTITUTE, FLORENCE

ECONOMICS DEPARTMENT

EUI Working Paper ECO No. 94/11

How Does the Hungarian Unemployment Insurance System Really Work?

JOHN MICKLEWRIGHT

and

GYULA NAGY 
All rights reserved.

No part of this paper may be reproduced in any form without permission of the authors.

(C) John Micklewright and Gyula Nagy

Printed in Italy in April 1994

European University Institute

Badia Fiesolana

I - 50016 San Domenico (FI)

Italy 


\title{
How Does The Hungarian Unemployment Insurance System Really Work?
}

\author{
John Mick lewright* and Gyula Nagy+
}

* Department of Economics, European University Institute, Florence, and Queen Mary and Westfield College, University of London

+ Department of Human Resources, Budapest University of Economics

December 1993

Abstract

Discussion of unemployment benefit in Hungary often takes place without adequate information on the functioning of the benefit system. We look at receipt of Unemployment Insurance (UI) benefit, using microdata drawn from administrative records of the benefit system. Taking a $10 \%$ sample of the stock of benefit recipients in March 1992, we analyse the distribution of benefit amounts and entitlement periods at that time and simulate the effect of changes introduced in 1993. Receipt is determined in a much more complex way than a casual look at the 'rules' might suggest. We also consider the impact of the income tax system and the relationship of benefit to both past and prospective earnings. We draw lessons for the analys is of unemployment benefit in other Eastern European countries in transition.

\section{Acknow ledgements}

We are grateful to the National Labour Centre for giving us access to anonymised microdata from the unemployment insurance system. We thank Gyorgy Lazar for his advice on the project and Zsuzsa Kovacs for her help in preparing the data for analysis. Financial support of the Ministry of Labour, the OTKA Fund of the Academy of Sciences, the EC TEMPUS scheme, and the European University Institute is gratefully acknowledged. Helpful comments on the paper were made at workshops organised by the ILO in Budapest and by the OECD in Paris. We thank in particular William Clatanoff for his comments in his role as the paper's discussant at the Paris workshop. The views expressed in the paper should not be attributed to the National Labour Centre or to any other institution. We bear sole responsibility for any mistakes the paper contains. 


\section{INTRODUCTION}

The introduction of unemployment benef it in Hungary in January 1989 was an important early step in the transition of the Hungarian economy to a market system. As in other Eastern European countries, an economic system that guaranteed jobs is being replaced by one that guarantees unemployment benef it (subject to certain conditions) in the event of job loss. Payment of unemployment benefit therefore helps underpin economic reform.

While there may be general agreement on this principle throughout Eastern Europe, the practice of the provision of unemployment benef it is the subject of much debate. At the macro level there are concerns about the level of public expenditure involved, and about the balance with expenditure on active labour market policies. Our focus in this paper is on the micro level, where the impact of benefit on both living standards and incentives to work depends crucially on how benefit systems actually function. Comment on systems in Eastern Europe is typically based on a look at selected parameters rather than on information on actual payments. But Western experience indicates that benefit schemes often work in a way that is not obvious from a reading of the rules of the schemes. Rules may interact in complicated ways. There may be administrative discretion and error in the way that rules are applied. In particular, calculations of the hypothetical benefit entitlement for an "average" worker may give a very misleading impression of how the benefit system works on the ground.

In this paper we look at a large sample of microdata on actual benefit payments in March 1992 to investigate how the Hungarian system does in fact work. The reader's appetite for the analys is may be whetted by Figure 1 , which shows the distribution of monthly UI payments in the data. The figure shows an enormous spike at one point. What kind of UI system produces such a distribution? Answering this question with the aid of data on actual payments sheds light on a number of issues, including living standards, incentives, and benefit administration. This allows discussion of reform of the benefit system in Hungary to be better informed than hitherto has been the case.

Our analysis is of a 1 in 10 sample of the stock of UI recipients on 20 March 1992, a sample of 37,166 individuals. Registered unemployment at this time stood at over 9 percent of the labour force. (By the summer of 1993 it had risen to 13 percent.) The data are drawn from the administrative records 
of the UI system held by the National Labour Centre (NLC), which collects information on each spell of UI receipt and stores it in computerised form. These records include some basic socio-economic data together with all details of the UI payments and of the information that is needed for their calculation such as previous earnings. There is ro information in the data on the unemployed who do not receive benefit (about 30 percent of the registered unemployed) nor do we know the household characteristics of benefit recipients, which are of considerable importance to discussion of both living standards and incentives. But the NLC data do have the advantage of providing precise information on benefit entitlements for a very large sample of individua $15 .{ }^{1}$

Section 2 considers how benefit amounts are determined in the Hungarian UI system. We demonstrate (i) the enormous impact of rules that might have been assumed to apply to only "special cases", (ii) the impact of "hidden changes" in the legislation over time, and (iii) the effect of several important administrative practices. We also simulate the impact on entitlements of the 1993 reform of the UI system. Section 3 analyses the relationship of UI payments to wages, distinguishing between a backwardlooking calculation that measures replacement of past income and a forwardlooking calculation that emphasises incentives to return to work. Section 4 considers how the picture is changed by consideration of progressive income taxation and other deductions, the impact of which is is quite notable and which is influenced in the case of the tax system by administrative arrangements for the unemployed. Section 5 analyses periods of entitlement to benefit, an aspect of UI which has seen considerable emphasis in the recent literature on disincentives. Section 6 draws conclusions for the case of UI in Hungary and spells out lessons for discussion of unemployment benefit in Eastern Europe more generally.

\section{THE ANATOMY OF THE HUNGARIAN UI SYSTEM}

A stylised view of UI is that it pays $x$ percent of past earnings for a maximum period of time of length $y$. While $x$ and $y$ are important parameters, an adequate description of UI rules in any country would go some way beyond

1 Like our data, the first annual wave of the TARKI household pane 1 survey refers to March 1992 but contains less than 300 unemployed persons (defined on a job search basis). 
these features (Atkinson and Micklewright, 1991). The existence of maximum and minimum benefit levels, the definition of 'past earnings', and the treatment of voluntary quits and of recurrent unemployment are examples of UI scheme details that have an important bearing on payments. There is insufficient room here to give all relevant details of the Hungarian UI system but in Table 1 we give some information including values of the parameters $x$ and $y$. (Amongst other things we neglect financing issues.) We focus on the scheme introduced in March 1991 (the '91 scheme'), and modified in January 1992 (the '92 scheme') and January 1993 (the '93 scheme'). The basic form of the 91,92 and 93 schemes is identical. The qualification periods for benefit, which depend on employment history in the previous 4 years, are the same, as is the structure of a falling $x$ with time unemployed (there are two benefit "periods") and a $y$ which varies with past employment history. ${ }^{2}$

The first point to make about the table is that the rules of the 91 and 92 schemes still determine the benefit payments of large numbers of the unemployed. The UI system in Hungary embodies the grandfathering principle; a claimant has his or her spell of benefit determined under the rules applying on the day of the claim. A person registering as unemployed in December 1992 receives benefit under the rules of the 92 scheme and is not affected by the introduction a month later of the 93 scheme. The dynamics of unemployment in Hungary imply that "grandfathering" results in changes to the UI system taking a considerable time to take full effect. As in several other Eastern European countries, the high unemployment rate in Hungary has until now resulted from a low outflow rate rather than a high inflow rate (Boeri, 1993). Thus there is a considerable lag before any new rules apply to the majority of the stock. No less than two-thirds of our March 1992 sample of the stock of UI recipients were still receiving benefit under the terms of the 1991 rules. We have also checked a sample from the register for April 1993. Only 1 in 5 persons received under the 93 scheme rules, the remaining 80 percent receiving under the 91 or 92 rules. The 1992 and 1993 revisions to the basic scheme appear largely to have been made to try and contain rising costs, but the

2 In addition to UI, the 91 scheme introduced a flat-rate "Career Beginner's" benefit for young people joining the labour market while the 92 scheme introduced a means-tested "Social Benefit" for those exhausting their ent it lement to UI. In March 1992 there were around 20,000 recipients of these two benefits compared to around 370,000 UI recipients. We focus exclusively on UI. Finally, there is a mandatory redundancy payments scheme which pays up to 6 months' wages for those with lengthy periods of service with their employers. Entitlement to UI begins only after redundancy pay has finished. 
grandfathering of ent it lements has clearly delayed the full impact on benefit expenditure.

The second point to note about Table 1 is that the rules determining benefit payments for claimants with low earnings have an enormous impact. For simplicity we describe the arrangements in the 92 scheme. If application of the relevant $x$ value (benefit/earnings ratio) produces a monthly benefit figure less than the minimum wage then benefit is set equal to the latter. But if the past earnings fall below the minimum wage then benefit is set equal to past earnings. This rule (and that relating to the maximum) results in the schedules relating benefit to wages having the piece-wise linear formulae illustrated in Figure 2 and implies that the benefit/earnings ratio depends on the previous level of earnings as well as the benefit "period". The thick solid line relates to a person in "period 1 " of the 92 scheme, the first $\%$ of the total entitlement period at that time. (The thin lines represent the 93 scheme, which we discuss below.) When earnings are more than 2.86 times the minimum wage there is a flat segment representing the maximum benefit level. There is a second flat segment when earnings are between 1.0 and 1.43 times the minimum wage. Here benefit is paid at the level of the minimum wage. The two sloping segments represent the formal $x$ value of 70 percent and the 100 percent rate that applies when earnings are beneath the minimum wage. The thick dashed line shows how the schedule is modified in "period 2" when $x$ is lower. The flat segment where benefit is paid at the minimum wage is substantially larger and maximum benefit is not attained until previous earnings are four times the minimum wage.

The formulae define four benefit "regimes": (i) benefit beneath the minimum wage, ( $i i)$ benefit at the minimum wage, (iii) benefit at the formal $x$ rate and, (iv) benefit at the maximum level. What is the relative importance in practice of each regime? Suppose that the incidence of unemployment was evenly distributed across the earnings distribution. Using data on the distribution of earnings in Hungary in September 1992 we assume that (a) benefit is determined by current earnings (rather than earnings in the previous 4 complete quarters), and (b) benefit is determined by the 92 scheme period 1 rules. ${ }^{3}$ We estimate the following distribution of regimes:

3 These data are from a large scale survey conducted by the Hungarian CSO of the earnings of persons working full-t ime for employers with 50 or more employees in September 1992 and are published in KSH (1993). 


\section{Benefit:}

below minimum wage at minimum wage

above min. wage and below maximum at the maximum men women

$\begin{array}{rr}1.9 & 2.6 \\ 7.5 & 14.5 \\ 50.3 & 55.4 \\ 48.3 & 27.5\end{array}$

$100.0 \quad 100.0$

The $x$ rate of 70 percent in the 92 scheme would apply in just over half of cases and the next most important regime would be the maximum benefit level. However, these calculations are a poor guide to the actual distribution of regimes amongst UI recipients, as may be seen from Table 2. Two-thirds of our sample of recipients in March 1992 receive benefit at the level of the minimum wage or less - 43 percent at the minimum and 23 percent below the minimum. Only 2 percent receive maximum benefit and slightly less than a third receive benefit determined by the $x$ applicable to the period (70 percent or 50 percent). The period 1 and period 2 values of $x$ are often the focus of discussion of the Hungarian UI system but by themselves they determine the benefit of only a minority of claimants. The majority have their benefit determined by the provisions relating to the minimum wage. The explanation for the shape of Figure 1 is now clear - the large spike reflects payments at or near the level of the minimum wage. Since benefit is a higher proportion of earnings for those in the bottom two regimes, one implication of Table 2 is that the Hungarian UI system redistributes income rather more than many people may realise.

There are some notable differences in the distribution of the sample across regimes by ent it lement period and benefit scheme and by gender. (There are no 92 scheme recipients in period 2 since no period 1 entitlements could have been exhausted between 1 January 1992 and our 20 March sample date; we exclude a negligible number of recipients under the 1989 rules.) Payments at or below the minimum wage occur for over 90 percent of claimants in period 2 of the 91 scheme. The same proportion of claimants in the 91 scheme period 1 and those in the 92 scheme (a11 of whom are also on period 1) are at or below the minimum - 63 percent - but in the 92 scheme there are more in the lowest regime. Only 15 percent of men have benefit beneath the minimum wage compared to 35 percent of women and over 80 percent of women are at or below the minimum.

Why do the patterns in Table 2 occur? The principal reason for the importance of the two lowest benefit regimes is a concentration of 
unemployment on persons from the lower part of the earnings distribution. This has a big impact on the distribution of regimes since the overall distribution displays only moderate dispersion (the Gini coefficients for the September 1992 data are 0.31 for men and 0.29 for women). Median earnings for women in the overall distribution in September 1992 were little more than double the minimum wage and only 2.5 times the minimum for men. So any concentration of unemployment on the lower paid makes the bottom two regimes very important since a figure of about 1.5 times the minimum wage represents their upper boundary. Just over half of our sample of UI recipients have a previous earnings figure of less than 1.5 times the minimum wage in force on the date they last worked. This compares with only 1 in 6 of the employed in September 1992. Over 10 percent of the unemployed had earnings beneath the minimum wage when last employed compared to only 2 percent of the employed (something that need not reflect a flouting of the legal minimum). And since women are lower paid on average a greater number of women receiving UI have benefit at or beneath the minimum wage. The importance of the bottom two regimes is an inevitable consequence of adjusting the benefit formula for the lower paid in an economy with only moderate earnings dispersion.

A contributory reason for the importance of the provisions surrounding low levels of benefit is the lack of indexing in the benefit calculations. It is common for discussion of UI schemes to refer to benefit being a fraction of "previous earnings" without explicit recognition of the period over which these are defined. The base period in the 91 scheme was the last month of work prior to the UI claim. (This may not immediately preceed UI receipt due intervening periods of sickness, military service etc, or to a suspension of benefit due to voluntary quitting - see Table 1). In the 92 and 93 schemes the base period is the last four complete quarters. In no scheme has there been indexing of base period earnings to allow for wage inflation (around 2530 percent annually in 1990-92) nor is there indexing of benefit payments during a spe11, except via changes in the minimum wage. ${ }^{4}$ We estimate that if benefit were based on the previous earnings figure indexed to March 1992 then the proportion of the sample in the bottom two regimes would fall from 66 percent to 53 percent.

The effect of a change in the base period in the 92 scheme is something

4

If the minimum wage is raised during unemployment then existing UI payments at or below the minimum were raised proportionately in the 91 and 92 schemes (although not in the 93 scheme). 
that we can detect empirically in the data. We estimate OLS regressions of the $\log$ of the previous earnings figure used by the NLC in benefit calculations, entering explanatory variables for years of schooling, age (and its square), months since last employment, a Budapest dummy, and a dummy for receipt under the 92 scheme. The equations are estimated separately for men and women and are restricted to those individuals in the March 1992 stock with a date of last employment on or after 1 0ctober 1991. The variable for months since last employment is present to pick up the impact of wage inflation in producing different earnings figures for persons with different dates of job loss. The 92 scheme dummy is entered to see if, holding other things equal, previous earnings for individuals receiving under this scheme are indeed lower. Each month since the date of last employment is estimated to reduce previous earnings by 2.5 percent for men and 2 percent for women. However, holding constant the date of last employment, 92 scheme recipients have previous earnings that are lower by 11-12 percent, which we take as evidence of the effect of the change in base period.

The change in base period represented a reduction in the generosity of benefit. This type of change is much less obvious to the casual observer than changes in the benefit-earnings ratios or entitlement periods. But although the latter may be more evident in the sense that prominent scheme parameters are changed, the impact of such changes is not always easy to see. This is well illustrated by the reforms of January 1993. The 93 scheme changed entitlement periods, formal benefit/earnings ratios, provisions surrounding lower levels of benefit, and the treatment of voluntary quits (see Table 1). Without simulation of their collective impact on entitlements with a sample of microdata it is difficult to come to any view as to the overall effect.

To guage the effect of the 1993 changes we apply the new rules to everyone in the March 1992 stock. (This exercise does not of course correspond to what happened to existing benefit recipients on lst January 1993; the grandfathering of existing claims means that the 93 scheme rules have been applied only to new claims beginning in 1993.) The first result is a reduction in the size of the stock of UI recipients by 16 percent. Two factors produce this effect. First, the increase in the waiting time for benefit to 6 months in the event of a voluntary quit affects almost half of job quitters receiving benefit in March 1992. Second, entitlement to UI of al1 those in the 91 scheme period 2 would cease immediately; the total entitlement periods under the 93 scheme are equal to those in period 1 of the 
91 scheme.

The impact on benefit levels is more complex. The benefit formulae in the 93 scheme are illustrated by the thin lines in Figure 2. The formal benefit-earnings ratio rises in both entitlement periods but many claimants would find that the changes in the length's of the entitlement periods shifted them out of the substantially shortened higher-ratio period 1 into the lowerratio period 2. We calculate that this happens to about half of claimants in period 1 in March 1992 and among the other half there are many in the bottom two regimes who experience no increase or who suffer a fall - see Figure 2. Overa11, and leaving aside those who have no entitlement remaining under the new rules, 16 percent of the sample experience a rise in benefit, 10 percent stay unchanged, while benefit falls in the remaining 74 percent of cases. ${ }^{5}$ The mean change in benefit is a fall of 5 percent.

Finally in this section we highlight two administrative details of the Hungarian UI system. Administrative practices may have an important effect on benefit receipt but can rarely be gleaned from reading the relevant legislation.

First, nearly 1 in 8 of the March 1992 stock are persons who had received benefit under the original scheme introduced in 1989 and who had been able to switch directly to receipt under the 91 or 92 schemes on expiry of entitlement without an intervening period of work. The 91 and 92 scheme rules concerning work history in the four years prior to claim appear to have been applied without regard to the fact that entitlement under an earlier set of rules had just ceased. This seems outside the spirit of the system, since the individuals concerned are able to extend a total entitlement period to benefit which exceeds that in any individual scheme. (Since benefit in March 1992 is based on the earnings in the job held before receipt under the 89 scheme, the individuals concerned are disproportionately concentrated in the bottom benefit regime.)

5

In making the calculations we have modelled the effect of changes in the provisions relating to low benefit levels by multiplying the minimum wage in March 1992 by $8600 / 9000$, which is the ratio of the key figure to the minimum wage in February 1993. Similarly, we have modelled the new maximum benefit amounts in the 2 periods of the 93 scheme by multiplying the 1992 minimum wage by the ratio of the levels of the new maxima with respect to the new minimum of 8600 forints. One feature we have not attempted to model is the difference in the base period for earnings between the 1991 and 1993 schemes (the base periods for earnings in the 92 scheme are the same as those in the 93 scheme). 
Second, if a person did not work in any of the four complete calendar quarters prior to the UI claim under the 92 (or 93) scheme, then the practice is to impute a figure that is often higher than the historic lasi job earnings figure. We calculate that imputation occurred in nearly 1 in 7 cases of receipt under the 92 scheme in our sample. Not surprisingly, many of these persons (about half) are benefit 'switchers' from the 89 scheme who in this case profit from the use of the imputed wage figure on top of the extended entitlement resulting from 'switching'.

This section has shown that receipt of benefit in Hungary is determined in a much more complex way than a casual glance at the 'rules' might suggest. The special provisions for individuals with low previous earnings, the lack of indexing of previous earnings, and certain administrative practices in the scheme, combine to make the more prominent formal parameters a limited guide to the scheme's outcomes.

\section{REPLACEMENT RATES}

The use of replacement rates to measure the generosity of benefit payments has figured prominently in the literature on unemployment benefits. At the same time, the concept is not always made clear and the term has been used to describe different sorts of calculations. First, there is the issue of whether the calculation is backward- or forward-looking. The former, measuring income when unemployed to that when last in work, is relevant to assessing the role of unemployment benefit in supporting past living standards. The latter, comparing income when unemployed to that which couid be received on the return to work, is relevant to measuring the disincentives produced by a benefit system. We make calculations of both.

The second issue is the definition of income taken into the calculations. We define the replacement rate as the ratio of UI payment to main job earnings. This definition is restrictive. Whether employed or unemployed, living standards will be affected by a 11 income sources of the claimant and of other members of the household (providing there is some income pooling among household members). Similariy, ail but the simolest model of job search behaviour accords a place to sources of income other than unemployment benef it and ma in job earnings (Atk inson and Mick lewright, 1985, chapter 5). Western literature on incomes of the unemployed tends to emphasise the role of income of other household members, especially the 
spouse. Discussion of unemployment benefit in Eastern Europe on the other hand often speculates on the role of supplementary "second economy" income (legal or illegal) which is particularly common in Hungary. The effect of second economy income is not obvious. It may be tied to the main job, and in this case our calculations may understate the income loss resulting from unemployment (UI being based on the main job earnings only). Or it may cont inue during unemployment, which would have an upward effect on replacement rates. Our data include nothing about second economy income or other sources of income in the household (we do not even know the marital status of claimants).

Thirdly, there is the issue of the tax treatment of benefit and of earnings. We focus in this section on the gross amounts of both income sources. In the next section we consider the impact of deductions due to tax and other reasons.

\section{Backward-looking calculations}

For our backward-looking calculations we take the ratio of benefit to the past earnings figure used to calculate benefit, having indexed the latter to March 1992, the date of our stock sample. ${ }^{6}$ The purpose of the indexing is to show the benefit received relative to previous earnings, had the latter moved in line with the national average - in other words the level of the current earning power of the previous job that is replaced by the current benefit payment.

Table 3 gives results in the form of the mean and standard deviation for each combination of benefit scheme and benefit 'regime' in March 1992. The importance of the indexing for obtaining a sensible picture of earnings replacement is shown most clearly by the separate values for the first and third regimes. Those in the third regime, with earnings below the minimum wage at the time of claiming UI, have a mean of 86 percent, not 100 percent, despite their benefit having been set equal to the level of their previous earnings. Those in the second regime, receiving at nominal benefit/wage rates of 70 or 50 percent, have means of 62 and 60 percent respectively in period 1 (nominal rate 70 percent) of the 91 and 92 schemes and 38 percent in the 91

- We used a monthly index of changes in average wages between the month of last employment and March 1992. For 92 scheme recipients we indexed from the middle of the last four complete quarters prior to last employment. 
scheme period 2 (nominal rate 50 percent). Those few persons with maximum benefit payments have a mean of 51 percent while those receiving benefit at the level of the minimum wage have a mean of 76 percent. (Had we not indexed the previous earnings the overa 11 mean rate would have been 13 percent points higher at 86 percent.)

The table implies that there is substantial variation in replacement rates within as we 11 as between regimes. Figure 3 shows the variation more directly and graphs the distributions separately for men and women, disaggregating also by age. The device used is a 'box-and-whiskers' plot; the bottom and top of the 'box' for each age group represents the upper and lower quartiles of the replacement rate for individuals of that age. The horizontal line dividing the box indicates the group median. The 'whiskers' attached to the box either have length equal to the 1.5 times the inter-quartile range or extend to the last observation in the distribution, whichever point comes first. In the former case the values of the replacement rate for the remaining outlier observations are marked (each point represents more than one individua 1). The width of each box is proportional to the number of persons in the age group.

The very small group of teenage men receiving UI have a median of 84 percent (and almost three-quarters have rates of 70 percent or more). The median then falls sharply with age and a 11 age-groups 25-29 and above have a a median close to 65 percent. But there is significant variation within each age-group - the inter-quartile range is typically about 15 percent points (higher in the bottom two age-groups) and the size of the 'whiskers' on each box show that there is further substantial variation at all ages. The greater concentration of women in the bottom two benefit regimes (at, and below, the minimum wage) is reflected in a substantially higher median replacement rates in each age-group other than for teenagers. The overa 11 median is 77 percent compared to 65 percent for men. The interquartile range is also larger nearly 25 points for most age groups.

\section{Forward-7ooking calculations}

The disincentives for the unemployed to search for new work or to accept job offers are best measured by the ratio of benefit to prospective rather than past earnings. The theoretical concept here is the mean of the wage offer distribution. The problem is in estimating this figure and our results 
here should be taken as illustrative rather than definitive. Our proxy is the fitted value from regressions estimated with our data of previous (indexed) earnings. We then calculate the ratio of UI to this figure. These calculations show the ratio of benefit to the earnings that we predict a person of the same sex would receive who was living in the same county with identical schooling, age, and occupation.

The regressions are run using earnings of individuals who are in general job losers (less than 10 percent of the sample entered unemployment as a result of a quit). Moreover, many of the jobs concerned may have disappeared forever as the result of economic restructuring. The wages associated with them, and hence our predicted earnings from the regressions, may not be an accurate guide to the average wage offers that might be received by our sample of unemployed persons.?

The regressions are reported in the Appendix and are est imated for those with a last date of employment on or after 1 0ctober 1991. The equations are estimated separately for men and women and include as an explanatory variable a cardinal index of occupation that is the log of average earnings (taking men and women together) in the individual's 4 digit occupation in May 1992. (These earnings figures are taken from a separate NLC survey of employed workers.) In including this variable we are not assuming that the individual restricts his job search to the same narrowly defined occupation that was held previously. Rather we hope that it measures an ability to achieve occupational success in the labour market that may be repeated in the future. The variable has a powerful effect in the regresssions - a 10 percent rise in occupational earnings is estimated to result in a 5 percent rise in actual earnings. But it is far from the case that including the occupational earnings variable results in a near perfect fit - only a quarter of the variance in log earnings is explained in each case. The estimated county effects confirm important regional differences in earnings in Hungary (the

\footnotetext{
We ran regressions with the same specification for the (much smaller) sample of employees in the first wave of the TARKI household panel (held in Spring 1992). (Due to differences between the two sources we had to use net earnings figures in both regressions and to exclude individuals in certain counties from the NLC data.) Most coefficients were very similar although we do formally reject the hypothes is of equality of parameters across the two samples.
}

${ }^{8}$ Of course, there may be many instances where actual occupational mobility associated with unemployment is downward. 
base is Budapest) which suggests that any disincentive effects of benefits may vary geographical1y. ${ }^{9}$

Table 4 reports means and standard deviations of forward-looking replacement rates with denominators calculated from these regressions. The calculations are made for different ranges of backward-looking replacement rate and benefit regime. The highest mean forward-looking rate, over 100 percent, is found for the regime in which there are the few persons receiving benefit at the maximum level, more than three-quarters of whom have backwardlooking rates of less than 60 percent. The regime with the lowest mean forward-looking rate, 62 percent, is where previous earnings were beneath the minimum wage at the time of claiming UI; in this regime two-thirds of claimants have backward-looking rates of 80 percent or more. And in every range of backward-looking rate the mean forward-looking rate is between 70 and 75 percent, although the standard deviations show that there is substantial variation in each case.

It is clear that there is no close correspondance between the backwardand forward-looking rates that we have calculated. This of course is due to the relatively low explanatory power of our earnings regressions - they explain well neither the unusually high previous earnings of people receiving maximum benefit nor the low earnings of people below the minimum wage. The previous earnings figure reflects unobserved influences on earnings that may be expected to continue - an individual "fixed effect". On this view, the calculations we made of backward-looking replacement rates would in addition serve well as forward-looking rates aimed at measuring incentives to work. On the other hand, arguments stressing mobility within a labour market might suggest that such fixed effects are likely to be small and that the earnings figure predicted on the basis of schooling, age and occupation may give a better guide to prospective earnings. Earnings mobility may be particularly high in a transforming economy.

Although our regressions may give only a rough indication of the mean of the wage offer distribution, the comparison of forward- with backwardlooking rates serves as a reminder that transition between jobs via a spell of unemployment may involve substantial changes in earnings. And the

9 If we exclude the occupational earnings variable, the main effect on the equations is a doubling in the size of the estimated college and university effects. (R-square declines by about 6 percent points.) If years of schooling is entered instead of the level variables the rate of return is estimated to be about 6 percent per year. 
discussion illustrates too that it is not obvious for whom the UI system produces the least incentive to work. It is a matter for judgment as well as factual evidence.

\section{DEDUCTIONS FROM BENEFITS AND EARNINGS}

To this point we have considered only gross benefits and earnings but account needs to be taken of deductions that are levied at source by employment offices paying benefits and by employers paying wages. Both earnings and UI payments in Hungary are subject to social insurance contributions and personal income taxation, and in addition alimony payments may be deducted at source. Like UI, a personal income tax is typically a new phenomenon in the transition economies of Eastern Europe (that in Hungary was introduced in 1988) and it is important to consider the interaction of the two.

The effect of social insurance contributions is unambiguously to increase replacement rates since the deduction rate when unemployed is lower than that when employed. Moreover, in each case the contribution is deducted at a single proportional rate so the effect is the same for all individuals. In 1992 the employed paid a 11 percent social insurance contribution on all earnings while the unemployed paid a 6 percent rate on all benefit. ${ }^{10}$ Allowing for these deductions, the median backward-looking rates of the previous section would rise about $3 \frac{1}{2}$ points for men and over 4 points for women - see Table 5 .

Alimony payments are deducted from benefit for a surprisingly large number of men - 8 percent overall and nearly 15 percent of men aged 35-44. (Less than 1 percent of unemployed women pay alimony). The average deduction rate is over 20 percent. If the same cash amount were also deducted at source from earnings then the effect in this case would be to lower replacement rates for the individuals concerned (except for those persons for whom benefit exceeded earnings). We calculate that the median backward-looking replacement rate for those paying alimony would fall by about five points.

The effect of personal income tax is the hardest to describe and illustrates well the difficulties of adequately representing the UI system.

10 Formally the deduction for the employed is made up of a 10 percent for "social insurance" and 1 percent for unemployment insurance (2 perccent in 1993). The unemployed pay no unemployment insurance contribution. 
On the face of it, the personal income tax system in Hungary would appear to raise average replacement rates. The system embodies the principle of independent taxation of husband and wife and in 1992 there were four marginal rates: $0,25,35$, and 40 percent. Unless both benefit and earnings are too low to attract tax, the progressive structure implies that benefit will a lways be taxed at a lower average rate than earnings (assuming gross benefit is less than gross earnings). (The progressive structure also implies that it is only with microdata that the distribution of actual tax liabilities can be deduced.)

We estimate that tax would be due on previous earnings (indexed to March 1992) for 88 percent of men and for 68 percent for women, whereas in the case of UI payments we estimate only 40 percent of men and 17 percent of women to be liable to tax. Although the average tax rates are in general modest - the mean values are 10 percent on earnings and 6 percent on benefit for men and 7 percent and 5 percent for women - an allowance for the tax system clearly does alter the picture for the majority of both men and women. Table 5 shows that the allowance for taxation raises the median male backward-looking replacement rate by 7 points compared to the situation where only social insurance is taken into account while the female rate rises by about half this figure. Allowance for both social insurance and taxation has brought the male median up by nearly 11 points. The gap between male and female rates is reduced by income taxation and the distributions for both genders are compressed somewhat.

These calculations assume that deductions at source from benefit made by employment offices follow the same procedure followed by employers for earnings. In the latter case, employers gross-up the monthly earnings figures to an annual basis, apply the tax formulae (which relate to annual income) and deduct the monthly equivalent from the earnings on behalf of the Ministry of Finance. This is known as "advance tax". Each individual then files a tax return at the end of the tax year and this may lead to an end-of-year adjustment. However, employment offices do not deduct advance tax from UI payments, except when the claimant requests it, or until cumulative benefit during the spell reaches the minimum annual threshold for the 25 percent marginal tax rate. Moreover, if the employment office does deduct advance tax it does so at a higher rate than if the person had been employed with earnings at the same level of the benefit. There is no obvious incentive to ask for advance tax to be deducted - the government in effect extracts an interest- 
free loan in this case (due to the excessive rate applied) but extends a loan to the end of the year if no deduction is made.

Inspecting the data we find that tax deductions from benefit are recorded in less than half of cases where we calculate that tax would be due if the employment offices followed the same procedure as employers. The comparison is complicated for those whose unemployment started in 1991 since the tax data in the files may cover that year as well. It is notable that among those men unemployed three months or less in March 1992, a tax deduction from benefit is recorded in the data in less than 10 percent of cases whereas our calculations in Table 5 involve a deduction in over 40 percent of cases.

The procedure followed by the employment offices implies that in many cases, and most apparently among those unemployed only a short time, the claimant receives UI gross of tax despite there being a positive tax liability on an annual basis. Where this occcurs, current monthly income from UI in relation to net monthly income from earnings were a job to be held is higher than if the employment office were to deduct advance tax in the same manner as employers. This applies only to the short-term monthly picture since at the end of the year any tax due on benefit must be paid, but if the individual discounts the future at a significant rate then the distinction may be an important one for behaviour.

Consideration of deductions from benefit and earnings alters the picture of the relationship between the two at any one time. It does so in a way that is not entirely straight forward but the basic effect is clear - the gross figures understate income replacement. In addition the picture over time will has also been affected due to the repeated changes in social insurance and income tax rates that have occured in Hungary. Finally, comparison of the Hungarian UI system with those in other countries is affected due to crosscountry differences in tax and social insurance systems.

\section{DURATION OF ENTITLEMENT}

The importance of considering the duration of entitlement as well as the level of unemployment benefit has been emphasised in recent literature on the disincentive effets of UI (e.g. Katz and Meyer, 1990). A concern with living standards of the unemployed should also lead us to look beyond the current income provided by benefit and consider how long the benefit is paid for.

Inspection of the rules of the UI system in Table 1 shows only the range 
of possible entitlement periods. Which periods are important in practice must be determined by looking at data on individuals' entitlements. Figure 4 shows the distribution of total days of entitlement (including those already used) for our stock sample, distinguishing between men and women. We also distinguish between the 91 and 92 schemes; the rules of the latter cut entitlement periods by a third (we exclude the few persons on the 89 scheme).

The most obvious feature of the distribution is that the modal entitlement period in both schemes is the maximum possible number of days, 2 years in the 91 scheme and 1.5 years in the 92 scheme, something generated by 4 continuous years of work prior to the claim for UI. This applies to about 40 percent of the stock in the 91 scheme and somewhat less than 30 percent in the 92 scheme. High unemployment is a recent phenomenon in Hungary. As a consequence the modal group in the stock at present has a good employment history. If unemployment becomes concentrated in the future on those with poor work histories then shorter entitlement periods will become more prominent.

The second notable feature is that the entitlement periods of women appear no shorter than those of men. So although women on average receive lower benefit amounts due to their lower previous earnings, they do not have shorter entitlement periods. This reflects the high participation rate of women in Hungary. This said, the restriction of our data to the unemployed who do receive UI should be noted. Among the unemployed as a whole there may be more women than men who fail to qualify for benefit on account of their emp loyment history.

Figure 5 gives the same information as Figure 4 in the form of the cumulative distributions, combining the sexes in this instance. The proportion of claimants with shorter entitlement periods is now more clear. Only about 10 percent in the 91 scheme and 15 percent in the 92 scheme have entitlement periods of 300 days or less. However, in interpreting these figures it is worth noting that the data include the benefit "switchers" whom we have identified - persons who appear to have exhausted benefit under the 89 scheme but who have been able to switch to the 91 or 92 schemes. Their recorded entitlement periods in our data refer only to the 91 or 92 schemes and must inevitably be less than the maximum. (The period of receipt under the 89 scheme took place in the 4 years prior to a claim under the 91 or 92 schemes.) If we exclude these persons (who make up 11 percent of the sample) from the calculations, the proportion of persons with a maximum ent it lement 
period rises to nearly 50 percent in the 91 scheme and over 30 percent in the 92 scheme.

Table 6 shows the proportion with the maximum entitlement period by education, age and sex. We again exclude the benefit 'switchers' from this table and we do not distinguish between 91 and 92 schemes. The breakdown by educational level shows that even among claimants with incomplete primary education (nearly a tenth of the sample) the proportion with the maximum period is 30 percent. The small group with college or university education has the highest proportion of persons with maximum entitlement - just over a half. In the modal groups of vocational schooling for men and primary schooling for women the proportions are 39 percent and 38 percent respectively. The variations with age are not surprising. The maximum entitlement period is secured by at least 4 years of continuous work and the young are less likely to satisfy this condition. Only a fifth of those aged 20-24 do so. Men aged 25-29 are notably less likely to have a maximum period than women of the same age (where the highest proportion with the maximum is found). One possibility for this is that although periods of military service (served only by men) are not taken into account in defining the 4 year period, the result of military service is to push the period over which employment history is considered back into late teens or early $20 \mathrm{~s}$, when the employment record is not so good.

Finally, we show in Figure 6 the cumulative distribution of remaining days of entitlement - the total days of entitlement (the focus of Figures 4 and 5 and of Table 6 ) minus the days of benefit already received in the current unemployment spe11. (This table includes the benefit 'switchers'.) The distribution marked " $A$ " shows the actual position on 20 March 1992 - just over half of the stock of UI recipients had 400 days or more of benefit entitlement still to run and just under three-quarters had 300 days or more. The distribution marked "B" shows what would have been the 'over-night' effect of introducing the 1993 scheme rules had there been no 'grandfathering' of existing entitlement. A sharp reduction in the remaining days of entitlement is apparent. The negative values represent the 12 percent of the sample who would have lost UI entitlement completely on account of their period already on benefit exceeding their new total entitlement. The median period of remaining entitlement among all claimants would be down to about 170 days. Only 1 in 10 of recipients would have 300 days or more left to run compared to three-quarters before the change. One implication of the low exit rate 
from unemployment in Hungary is that shorter entitlement periods in the 1993 scheme can be expected to result in much higher numbers of unemployed exhausting their entitlement to UI and then submitting a claim to means-tested social benefit.

\section{CONCLUSIONS}

Our analysis has shown the importance of looking at actual samples of unemployed people in Eastern European countries in order to understand how emerging UI systems work. A scheme's outcomes cannot be logically deduced from merely inspecting the most prominent "rules". This has implications not just for evaluation of labour market and income support policy in any one country, but also for attempts to compare unemployment benefit systems across the region, as in Burda (1993).

Our principal findings for Hungary are as follows.

Rules determining the benefit of claimants with low previous earnings have an enormous impact in practice. These applied in March 1992 to 4 out of 5 women and more than 1 in 2 men.

Median ratios of gross benefit to gross (indexed) previous earnings in March 1992 were 65 percent for men and 78 percent for women, but the distributions displayed considerable dispersion. (The bottom decile for men was 53 percent and the top decile 90 percent, these being associated with high and low previous earnings respectively.) Allowance for deductions increased the medians by up to 10 percent points.

Aspects of the administration of the UI system and its relationship with the income tax system need re-examination. Nearly 1 in 8 of the March 1992 stock of benefit recipients were persons who seem to have been able to obtain extended entitlement to benefit by switching between successive benefit schemes. If the same procedures were applied by employment offices administering benefit as are applied by employers paying wages then tax would be deducted from the unemployed much more frequently than appears to be the case. 
- $\quad$ The good employment histories of most people receiving UI in March 1992 meant that the modal entitlement period to benefit was the maximum.

- The "grandfathering" of existing claims when the rules change means that the legislative intent of reforms to the UI scheme (especially those relating to the duration of entitlement) has been considerably delayed in effect, on account of the low exit rate from unemployment. Only 1 in 5 persons with UI in April 1993 received under the rules introduced in January of that year.

While our results relate to Hungary, several of them are relevant to the debate on unemployment benefit in other Eastern European countries. A low turnover in the unemployed pool is found in a number of countries in the region (Boeri, 1993) which adds importance to the question of whether to grandfather existing claims when the rules change. It also means that reductions in entitlement periods can often be expected to bind in practice. The prominent impact in Hungary of rules relating to recipients with low previous earnings stems from the shape of the earnings distribution and the higher incidence of unemployment among the lower paid. An analogous impact of such rules may exist in other countries in the region with earnings-related schemes and a similar degree of earnings dispersion. Unemployment benefit is a new phenomenon in all countries in Eastern Europe and we would be surprised if a 11 administrative problems of the various schemes have been satisfactorily resolved. Similarly, the interaction of unemployment benefit and new personal income tax systems is an issue which arises throughout the region. Measures of "backward-looking" earnings replacement in any country will be poor measures of the incentive to return to work at an individual level if a period of unemployment results in significant earnings mobility.

There are several issues relevant to the discussion of unemployment benefit that we have been unable to consider with the administrative microdata which we have used. These need investigation throughout Eastern Europe. We have not been able to study who qualifies for UI and who does not. We have been unable to look at the household circumstances of the unemployed. We have had no information on job search behaviour. These are all subjects which require investigation with household surveys and the collection and analys is of such data must be seen as a priority in the investigation of the unemployed and of unemployment benefit in Eastern Europe. 


\section{$\underline{\text { References }}$}

Atkinson A B and Mick lewright J, 1985, Unemployment Benefits and Unemployment Duration, STICERD Occasional Paper 6, London School of Economics.

Atkinson A B and Mick lewright J, 1991, "Unemployment Compensation and Labor Market Transitions: A Critical Review", Journal of Economic Literature, 29(4), 1679-1727.

Boeri, T, 1993, "Labour Market Flows and the Persistence of Unemployment in Central and Eastern Europe", paper presented at OECD workshop on the persistence of unemployment in Central and Eastern Europe, Paris, 30 September-2 0ctober, 1993.

Burda, M, 1993, "Unemp loyment, Labour Markets and Structural Change in Eastern Europe" Economic Policy, 16, 101-137.

Katz L and Meyer B, 1990, "The Impact of Potential Duration of Unemployment Benefits on the Duration of Unemployment Outcomes", Journal of Public Economics, 41(1), 45-72.

KSH, 1993, Kereseti aranyok a nemzetgazdasagban, Apri1. 


\section{Table 1: Unemployment Insurance in Hungary}

\section{March 1991 ("91 scheme")}

a) duration of entitlement varying from 6 to 24 months depending on employment record in last 4 years.

b) base earnings the last monthly basic wage plus bonus payments in the previous 12 months

c) benefit set at:

$70 \%$ of earnings for lst half of entitlement ("period 1")

$50 \%$ of earnings for 2 nd half of entitlement ("period 2")

d) if benefit calculated as less than the minimum wage, benefit is set equal to the minimum wage. However, if previous earnings less than the minimum wage then benefit set equal to previous earnings. Maximum benefit 3 times the minimum wage.

e) voluntary quitting results in a 3 month wait for benefit

\section{January 1992 ("92 scheme")}

a) "period 2" of entitlement cut by $50 \%$.

b) base period for earnings the last 4 complete calendar quarters

c) maximum benefit 2 times the minimum wage.

d) where entry to unemployment is through job loss with severance pay (introduced in January 1992) there is a waiting period for benefit equal to the duration of severance pay (severance pay a maximum of 6 months)

\section{January 1993 ("93 scheme")}

a) total duration of entitlement half that of 91 scheme (i.e. equal to length of 91 scheme "period 1").

b) benefit set at:

$75 \%$ of earnings for 1 st quarter of entitlement ("period 1") $60 \%$ of earnings for rest of entitlement ("period 2")

c) maximum benefit 18,000 forints per month in "period 1" and 15,000 in "period 2". If benefit calculated as less than 8,600 forints, benefit is set equal to 8,600 . However, if previous earnings less than 8,600 then benefit set equal to previous earnings. (Minimum wage equal to 9,000 forints from 1 February 1993.)

d) waiting period following a voluntary quit extended to 6 months

Notes:

1) In each case we list only the changes made to the existing scheme.

2) Benefit is calculated as a \% of gross earnings and is subject to income tax and a (reduced) social insurance deduction. (See Section 4.) 
Table 2: Benef it Regime by Benef it Type

(10\% of UI Recipients on '91 and '92 schemes, 20 March 1992)

$$
\begin{aligned}
& \text { frequency } \\
& \text { row } \% \\
& \text { column } \%
\end{aligned}
$$

\begin{tabular}{|c|c|c|c|c|c|c|}
\hline $\begin{array}{l}\text { Benef it } \\
\text { regime }\end{array}$ & $\begin{array}{l}\text { B } \\
\text { period } 1\end{array}$ & $\begin{array}{l}\text { nef it type } \\
\text { '91 scheme } \\
\text { period } 2\end{array}$ & $\begin{array}{l}92 \text { scheme } \\
\text { period } 1\end{array}$ & Total & Total & Total \\
\hline$<\min W$ & $\begin{array}{l}3539 \\
41.2 \\
17.6\end{array}$ & $\begin{array}{l}1487 \\
17.3 \\
34.2\end{array}$ & $\begin{array}{l}3562 \\
41.5 \\
28.1\end{array}$ & $\begin{array}{r}8588 \\
100.0 \\
23.1\end{array}$ & $\begin{array}{l}3357 \\
15.2\end{array}$ & $\begin{array}{l}5231 \\
34.9\end{array}$ \\
\hline $\min W$ & $\begin{array}{l}9120 \\
56.8 \\
45.4\end{array}$ & $\begin{array}{l}2555 \\
15.9 \\
58.8\end{array}$ & $\begin{array}{l}4387 \\
27.3 \\
34.6\end{array}$ & $\begin{array}{r}16062 \\
100.0 \\
43.3\end{array}$ & $\begin{array}{l}9117 \\
41.3\end{array}$ & $\begin{array}{l}6945 \\
45.3\end{array}$ \\
\hline$>\min W$ & $\begin{array}{l}7154 \\
60.8 \\
35.6\end{array}$ & $\begin{array}{l}298 \\
2.5 \\
6.9\end{array}$ & $\begin{array}{l}4312 \\
36.7 \\
34.0\end{array}$ & $\begin{array}{r}11764 \\
100.0 \\
31.7\end{array}$ & $\begin{array}{l}9050 \\
40.9\end{array}$ & $\begin{array}{l}2714 \\
18.1\end{array}$ \\
\hline $\max$ ben & $\begin{array}{r}273 \\
38.9 \\
1.4\end{array}$ & $\begin{array}{r}7 \\
1.0 \\
0.2\end{array}$ & $\begin{array}{r}421 \\
60.1 \\
3.3\end{array}$ & $\begin{array}{r}701 \\
100.0 \\
1.9\end{array}$ & $\begin{array}{l}579 \\
2.6\end{array}$ & $\begin{array}{l}122 \\
0.8\end{array}$ \\
\hline Total & $\begin{array}{r}20086 \\
54.1 \\
100.0\end{array}$ & $\begin{array}{r}4347 \\
11.7 \\
100.0\end{array}$ & $\begin{array}{r}12682 \\
34.2 \\
100.00\end{array}$ & $\begin{array}{l}37115 \\
100.0 \\
100.0\end{array}$ & $\begin{array}{l}22103 \\
100.0\end{array}$ & $\begin{array}{l}15012 \\
100.0\end{array}$ \\
\hline
\end{tabular}

Men and Women

Men Women 


\section{Table 3: Mean Backward-Looking Replacement Rates}

(10\% of UI recipients in the '91 and '92 schemes, 20 March 1992)

Replacement rate defined as 100 *(UI benefit/previous earnings indexed for average wage change to March 1992)

\section{Means}

(Standard Deviations)

\begin{tabular}{|c|c|c|c|c|c|}
\hline $\begin{array}{l}\text { Benefit } \\
\text { type }\end{array}$ & $<\min W$ & $\begin{array}{l}\text { nefit } r \\
\text { min } w\end{array}$ & e $\min W$ & $\max$ ben & Tota 1 \\
\hline $\begin{array}{l}91 \text { scheme } \\
\text { period } 1\end{array}$ & $\begin{array}{c}89.9 \\
(13.8)\end{array}$ & $\begin{array}{c}79.5 \\
(14.3)\end{array}$ & $\begin{array}{l}61.9 \\
(5.2)\end{array}$ & $\begin{array}{c}52.3 \\
(10.2)\end{array}$ & $\begin{array}{c}74.7 \\
(15.9)\end{array}$ \\
\hline $\begin{array}{l}91 \text { scheme } \\
\text { period } 2\end{array}$ & $\begin{array}{c}80.0 \\
(15.5)\end{array}$ & $\begin{array}{c}68.4 \\
(19.0)\end{array}$ & $\begin{array}{l}38.3 \\
(5.1)\end{array}$ & $\begin{array}{l}36.8 \\
(6.2)\end{array}$ & $\begin{array}{c}70.3 \\
(20.1)\end{array}$ \\
\hline '92 scheme & $\begin{array}{l}83.4 \\
(7.6)\end{array}$ & $\begin{array}{l}72.4 \\
(9.4)\end{array}$ & $\begin{array}{l}60.1 \\
(4.1)\end{array}$ & $\begin{array}{l}49.5 \\
(9.0)\end{array}$ & $\begin{array}{c}70.4 \\
(12.4)\end{array}$ \\
\hline Total & $\begin{array}{c}85.6 \\
(12.9)\end{array}$ & $\begin{array}{c}75.9 \\
(14.9)\end{array}$ & $\begin{array}{l}60.7 \\
(6.2)\end{array}$ & $\begin{array}{l}50.5 \\
(9.7)\end{array}$ & $\begin{array}{c}72.8 \\
(15.7)\end{array}$ \\
\hline
\end{tabular}

Note: We have excluded from the table 1,799 individuals in the 92 scheme for whom the date of last employment does not fall in the four complete quarters prior to UI claim since in this case the NLC imputes the last earnings figure and indexation of thhis makes little sense. Otherwise cell frequencies are as in Table 2. 


\section{Table 4: Mean Forward-Looking Replacement Rates}

(10\% of UI recipients in the '91 and '92 schemes, 20 March 1992)

Replacement rate defined as $100 *$ (UI benefit/predicted earnings)

level of

Mean Forward- looking rate

(Standard deviation)

backward-

looking

replacement

$\begin{aligned} & \text { replacement } \\ & \text { rate }(\%)\end{aligned} \mid<\min W \quad \begin{aligned} & \text { benefit regime } \\ & \min W\end{aligned} \quad \min W \quad \max$ ben Total

\begin{tabular}{|c|c|c|c|c|c|}
\hline$<60$ & $\begin{array}{c}53.3 \\
(14.4) \\
225\end{array}$ & $\begin{array}{c}64.5 \\
(14.6) \\
1891\end{array}$ & $\begin{array}{c}76.6 \\
(21.6) \\
2751\end{array}$ & $\begin{array}{r}99.1 \\
(29.9) \\
559\end{array}$ & $\begin{array}{c}73.7 \\
(23.0) \\
5426\end{array}$ \\
\hline $60-79$ & $\begin{array}{c}58.6 \\
(15.3) \\
2331\end{array}$ & $\begin{array}{c}70.5 \\
(14.3) \\
7715\end{array}$ & $\begin{array}{c}81.6 \\
(21.5) \\
8362\end{array}$ & $\begin{array}{c}111.9 \\
(31.8) \\
105\end{array}$ & $\begin{array}{c}76.8 \\
(23.5) \\
18513\end{array}$ \\
\hline $80-99$ & $\begin{array}{c}63.5 \\
(17.0) \\
4145\end{array}$ & $\begin{array}{c}76.9 \\
(14.5) \\
4663\end{array}$ & . & . & $\begin{array}{c}70.6 \\
(17.1) \\
8808\end{array}$ \\
\hline $100-$ & $\begin{array}{c}65.4 \\
(17.2) \\
1295\end{array}$ & $\begin{array}{c}80.6 \\
(15.2) \\
1098\end{array}$ & . & : & $\begin{array}{c}72.5 \\
(18.0) \\
2393\end{array}$ \\
\hline Total & $\begin{array}{c}62.1 \\
(16.7) \\
7996\end{array}$ & $\begin{array}{l}72.4 \\
(15.2) \\
15367\end{array}$ & $\begin{array}{l}80.3 \\
(21.6) \\
11113\end{array}$ & $\begin{array}{r}101.2 \\
(30.5) \\
664\end{array}$ & $\begin{array}{l}73.1 \\
(19.7) \\
35140\end{array}$ \\
\hline
\end{tabular}


Table 5: Backward-Looking Replacement Rates with Different Treatment of Deductions

Men

$\begin{array}{lll}\text { Bottom } & \text { Median } & \text { Top } \\ \text { Decile } & & \text { Decile }\end{array}$

1) No Deductions from

53.2

65.2

90.0

benefit or earnings

56.2

68.9

94.6

deducted

3) Social Insurance and Income Tax

64.4

75.9

95.8 deducted

1) No Deductions from benefit or earnings 2) Social Insurance deducted

3) Social Insurance and Income Tax deducted

Women

Bottom Median Top

Decile Decile

$\begin{array}{lll}60.4 & 77.9 & 100.0 \\ 63.8 & 82.2 & 106.0 \\ 70.9 & 85.6 & 106.1\end{array}$

Note:

1. Social Insurance includes an unemployment insurance contribution in the case of earnings

2. Tax has been calculated on a full-year basis - see main text.

3. Sample as in Table 3. 
Table 6: Maximum Entitlement Period by Educational Level, Age and Sex

(UI recipients excluding benefit 'switchers')

a) Educational level

\begin{tabular}{|c|c|c|c|c|}
\hline \multirow[b]{2}{*}{$\begin{array}{c}\text { Educational } \\
\text { leve } 1\end{array}$} & \multicolumn{2}{|c|}{ Men } & \multicolumn{2}{|c|}{ Women } \\
\hline & $\begin{array}{l}\text { Percent } \\
\text { with max. } \\
\text { eligib. }\end{array}$ & $\begin{array}{l}\text { No. of } \\
\text { obs. }\end{array}$ & $\begin{array}{l}\text { Percent } \\
\text { with max. } \\
\text { eligib. }\end{array}$ & $\begin{array}{l}\text { No.of } \\
\text { obs. }\end{array}$ \\
\hline $\begin{array}{l}\text { incomp. primary } \\
\text { primary } \\
\text { vocational } \\
\text { vocational sec. } \\
\text { general sec. } \\
\text { college, univ. }\end{array}$ & $\begin{array}{l}30.9 \\
32.4 \\
38.9 \\
47.9 \\
39.5 \\
51.3\end{array}$ & $\begin{array}{r}1859 \\
6452 \\
8265 \\
1847 \\
626 \\
562\end{array}$ & $\begin{array}{l}30.4 \\
37.5 \\
40.6 \\
49.0 \\
46.9 \\
50.4\end{array}$ & $\begin{array}{r}1227 \\
6386 \\
2738 \\
1430 \\
1285 \\
278\end{array}$ \\
\hline Total & 36.9 & 19611 & 39.8 & 13344 \\
\hline
\end{tabular}

b) Age

\begin{tabular}{c|cr|rr|}
\multicolumn{4}{c}{ Men } & \multicolumn{2}{c}{ Women } \\
$\begin{array}{c}\text { Age } \\
\text { group }\end{array}$ & $\begin{array}{l}\text { Percent } \\
\text { with max. } \\
\text { eligib. }\end{array}$ & $\begin{array}{r}\text { No.of } \\
\text { obs. }\end{array}$ & $\begin{array}{l}\text { Percent } \\
\text { with max. } \\
\text { eligib. }\end{array}$ & $\begin{array}{r}\text { No.of } \\
\text { obs. }\end{array}$ \\
\hline-19 & 0.3 & 313 & 1.1 & 265 \\
$20-24$ & 19.7 & 3025 & 19.0 & 1403 \\
$25-29$ & 34.0 & 2836 & 46.0 & 1626 \\
$30-39$ & 40.4 & 5988 & 43.3 & 4399 \\
$40-49$ & 42.7 & 4545 & 45.4 & 3713 \\
$50-$ & 44.6 & 2904 & 37.0 & 1938 \\
\hline Total & 36.9 & 19611 & 39.8 & 13344
\end{tabular}

Note:

1. Benefit 'switchers' are excluded from this table. 
Appendix: Regressions of Log of Previous (Indexed) Earnings

(UI recipients in 91 and 92 schemes with date of last employment on or after 1 October 1991)

\begin{tabular}{|c|c|c|c|c|}
\hline & \multicolumn{2}{|c|}{ Men } & \multicolumn{2}{|c|}{ Women } \\
\hline & Coef. & $\mathrm{t}$ & Coef. & $\mathrm{t}$ \\
\hline $\begin{array}{l}\text { Constant } \\
\text { Schooling }\end{array}$ & 3.81 & 20.9 & 4.88 & 21.6 \\
\hline $\begin{array}{l}\text { primary (or less) } \\
\text { vocational second. } \\
\text { general secondary } \\
\text { college } \\
\text { university }\end{array}$ & $\begin{array}{r}.260 \\
.079 \\
-.017 \\
.196 \\
.269\end{array}$ & $\begin{array}{r}3.5 \\
5.9 \\
-0.7 \\
6.6 \\
7.1\end{array}$ & $\begin{array}{r}-.361 \\
.094 \\
.033 \\
.316 \\
.337\end{array}$ & $\begin{array}{r}-2.8 \\
5.0 \\
1.7 \\
7.6 \\
5.5\end{array}$ \\
\hline $\begin{array}{l}\text { Age } \\
\text { age } \\
\text { age squared/100 } \\
\text { primary*age } \\
\text { primary*age-sq/100 }\end{array}$ & $\begin{array}{r}.032 \\
-.033 \\
-.014 \\
.013\end{array}$ & $\begin{array}{r}9.4 \\
-7.6 \\
-2.9 \\
2.1\end{array}$ & $\begin{array}{r}-.005 \\
.018 \\
.022 \\
-.036\end{array}$ & $\begin{array}{r}-0.9 \\
2.2 \\
2.9 \\
-3.5\end{array}$ \\
\hline $\begin{array}{l}\text { Average occupational } \\
\text { earnings (log) } \\
\text { County }\end{array}$ & .526 & 29.8 & .461 & 21.6 \\
\hline $\begin{array}{l}\text { Baranya } \\
\text { Bacs } \\
\text { Bekes } \\
\text { Borsod } \\
\text { Csongrad } \\
\text { Fejer } \\
\text { Gyor } \\
\text { Hajdu } \\
\text { Heves } \\
\text { Komarom } \\
\text { Nograd } \\
\text { Pest } \\
\text { Somogy } \\
\text { Szabolcs } \\
\text { Szolnok } \\
\text { Tolna } \\
\text { Vas } \\
\text { Veszprem } \\
\text { Zala }\end{array}$ & $\begin{array}{l}-.127 \\
-.180 \\
-.138 \\
-.241 \\
-.135 \\
-.034 \\
-.114 \\
-.166 \\
-.163 \\
-.040 \\
-.099 \\
-.067 \\
-.185 \\
-.282 \\
-.147 \\
-.179 \\
-.200 \\
-.094 \\
-.259\end{array}$ & $\begin{array}{l}-5.5 \\
-9.3 \\
-6.8 \\
-13.2 \\
-6.1 \\
-1.5 \\
-4.6 \\
-7.9 \\
-6.9 \\
-1.7 \\
-4.2 \\
-3.4 \\
-7.2 \\
-14.9 \\
-7.4 \\
-6.9 \\
-7.3 \\
-4.0 \\
-9.2\end{array}$ & $\begin{array}{l}-.146 \\
-.197 \\
-.180 \\
-.271 \\
-.204 \\
-.075 \\
-.164 \\
-.254 \\
-.216 \\
-.139 \\
-.287 \\
-.131 \\
-.193 \\
-.268 \\
-.238 \\
-.158 \\
-.247 \\
-.174 \\
-.253\end{array}$ & $\begin{array}{l}-5.0 \\
-8.1 \\
-6.6 \\
11.6 \\
-6.8 \\
-2.6 \\
-5.2 \\
-9.8 \\
-7.4 \\
-4.5 \\
-9.7 \\
-5.4 \\
-6.1 \\
11.1 \\
-8.8 \\
-4.7 \\
-6.9 \\
-6.3 \\
-7.3\end{array}$ \\
\hline Adj R-square & 0.261 & & 0.249 & \\
\hline Number of observation & 9,117 & & 5,832 & \\
\hline
\end{tabular}




\section{Figure 1}

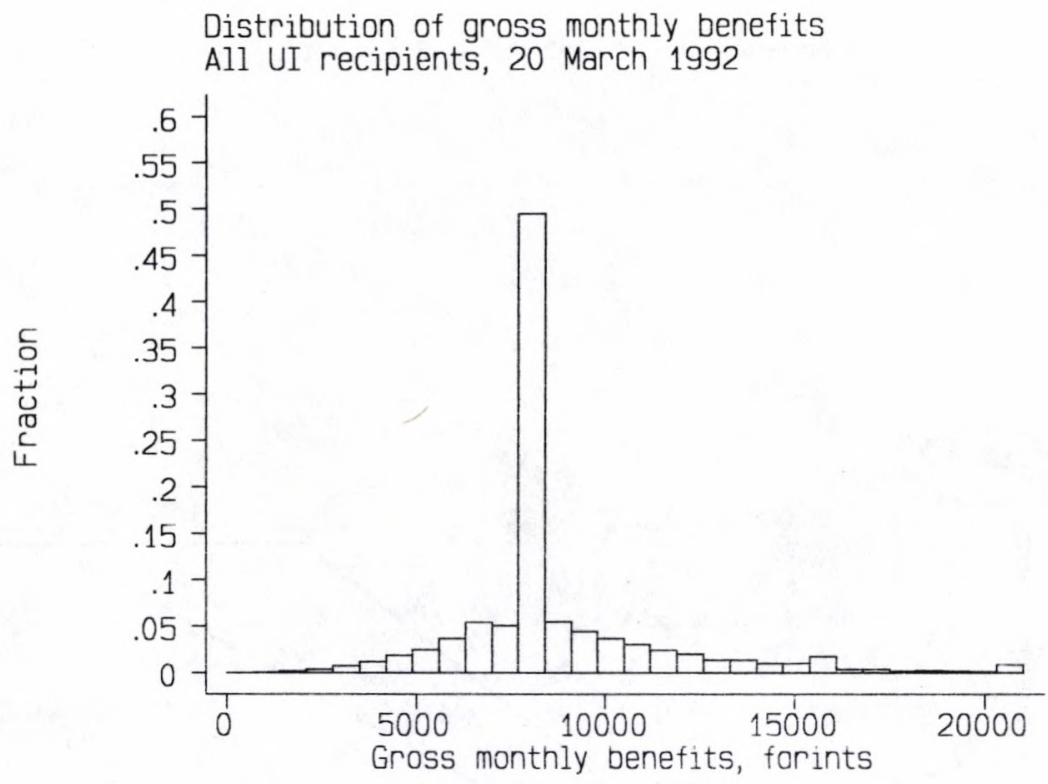




\section{Figure 2}

Benefit Formulae in the 1992 and 1993 Schemes

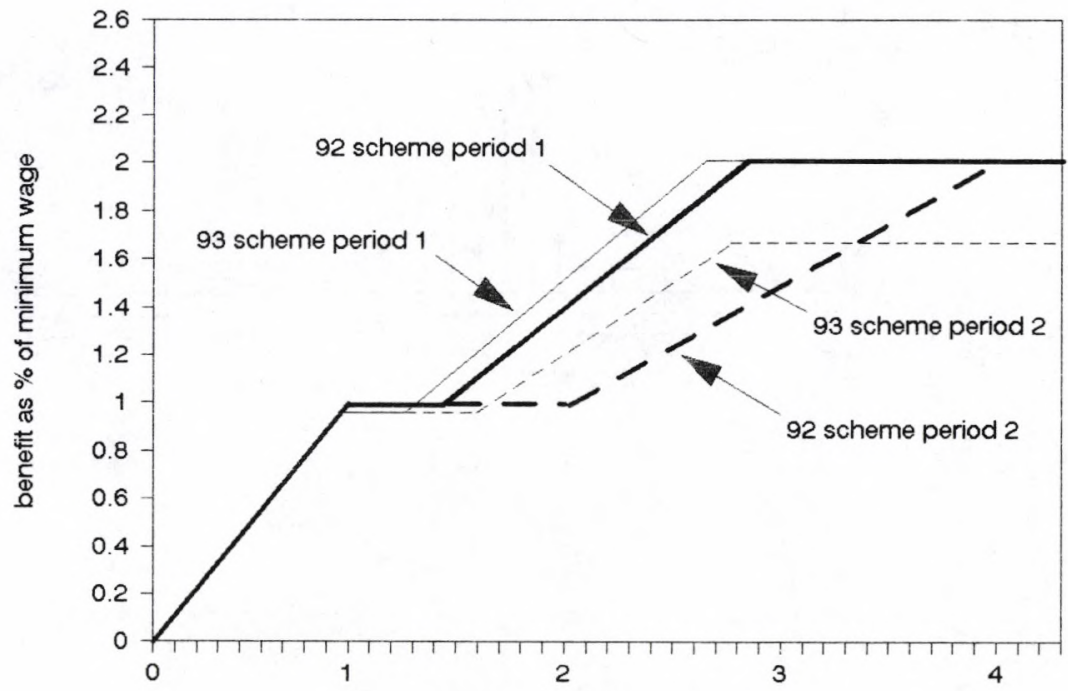

previous earnings as $\%$ of minimum wage 


\section{Figure 3}

Distribution of backward-looking replacement rate Males
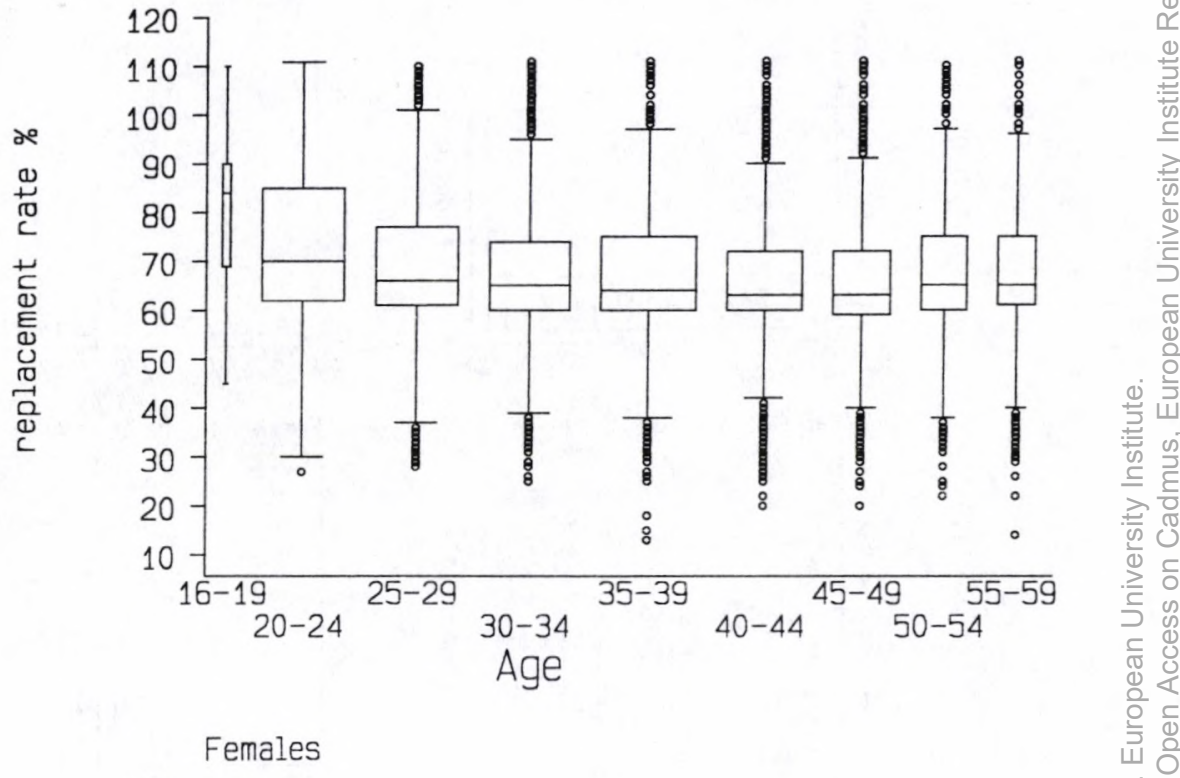

Females

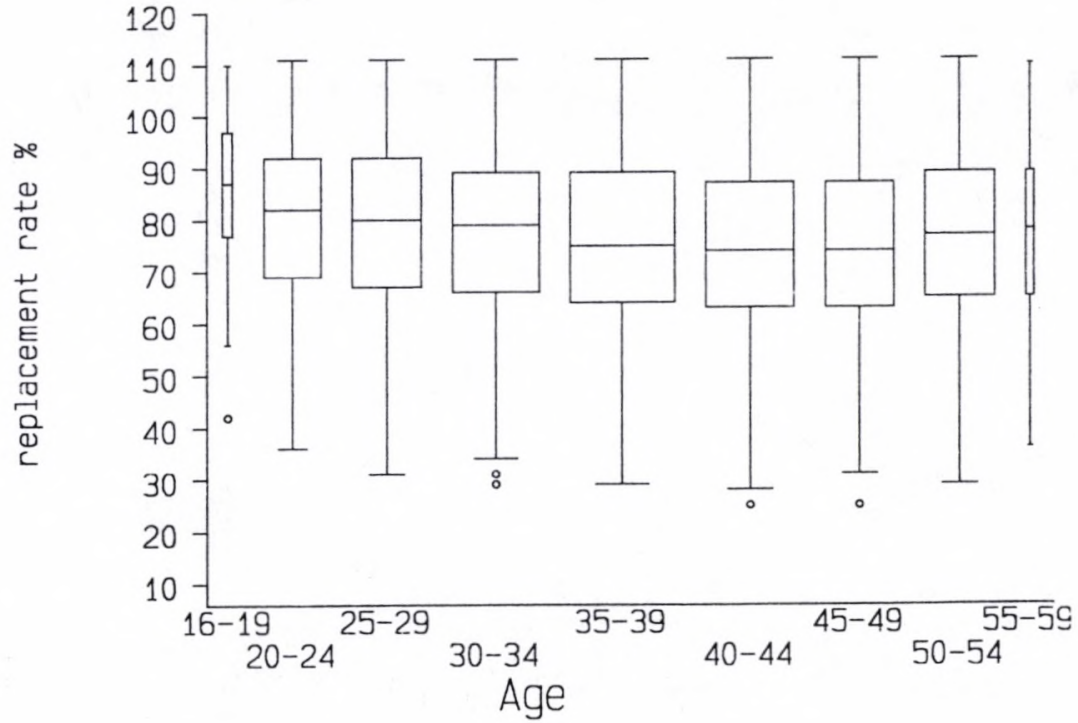

(1) 


\section{Figure 4}

Distributions of total eligibility periods

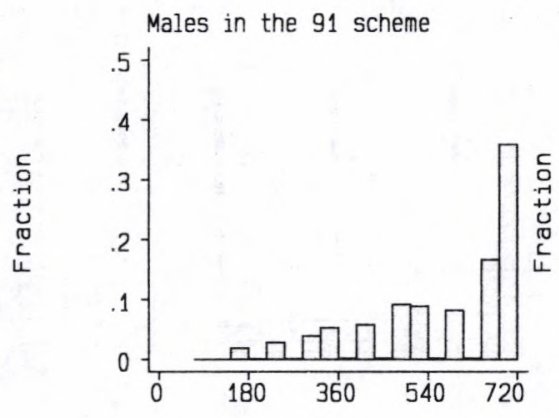

Males in the 92 scheme

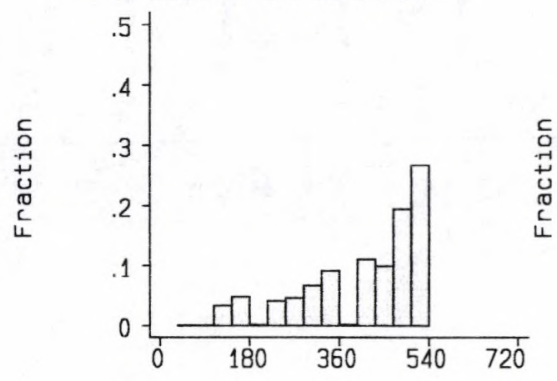

Females in the 91 scheme

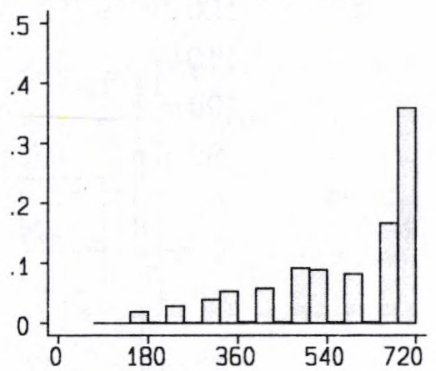

Females in the 92 scheme

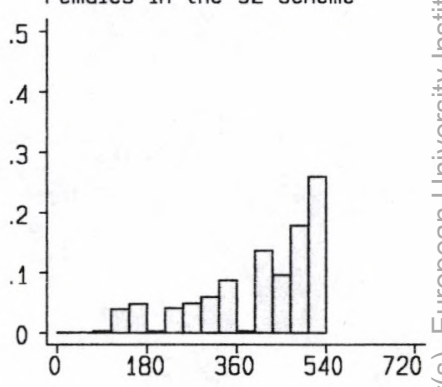

Eligibility period, days 


\section{Figure 5}

Cumulative distribution of total eligibility period

All U.I. recipients in the 1991 scheme

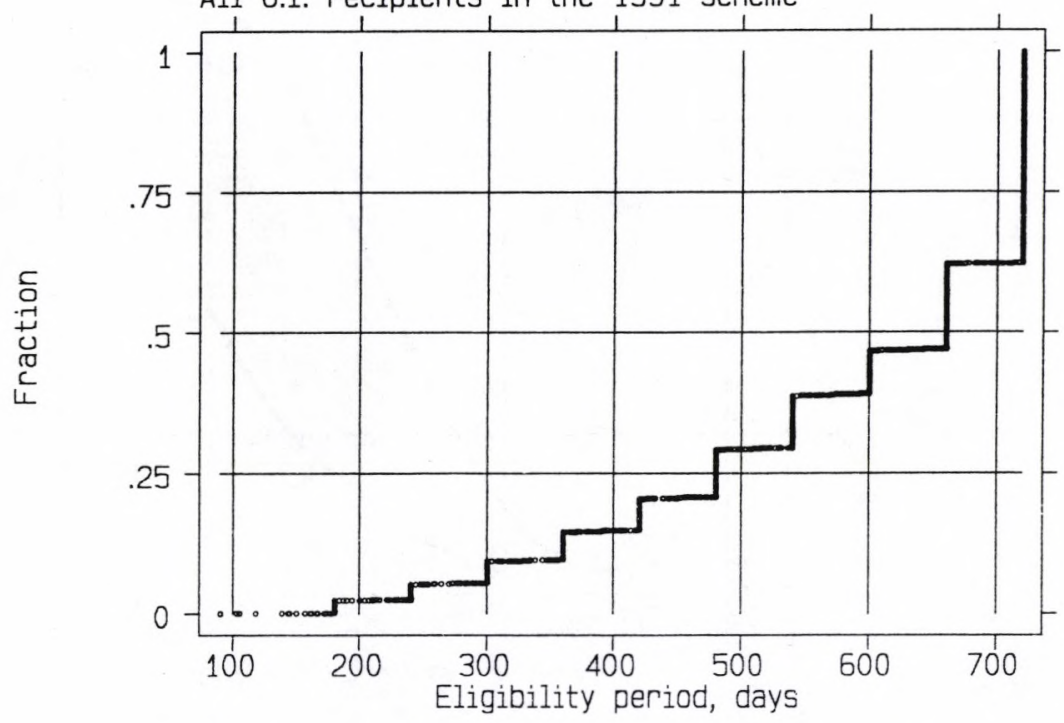

Cumulative distribution of total eligibility period All U.I. recipients in the 1992 scheme

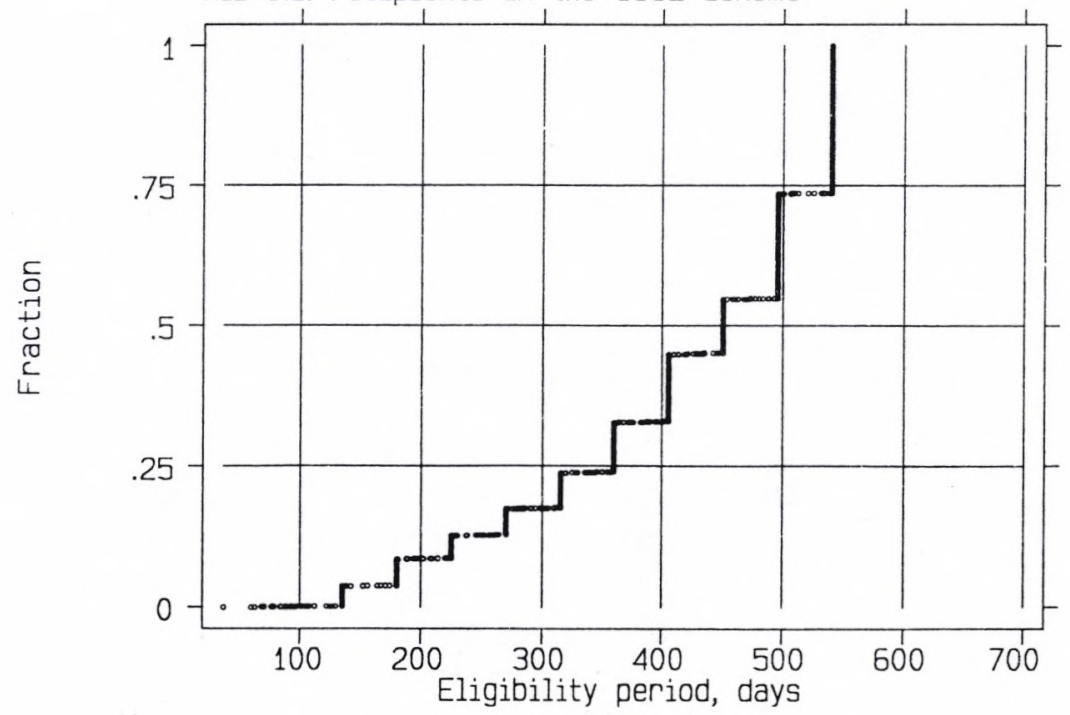




\section{Figure 6}

Cumulative Distribution of Remaining Days of UI Entitlement

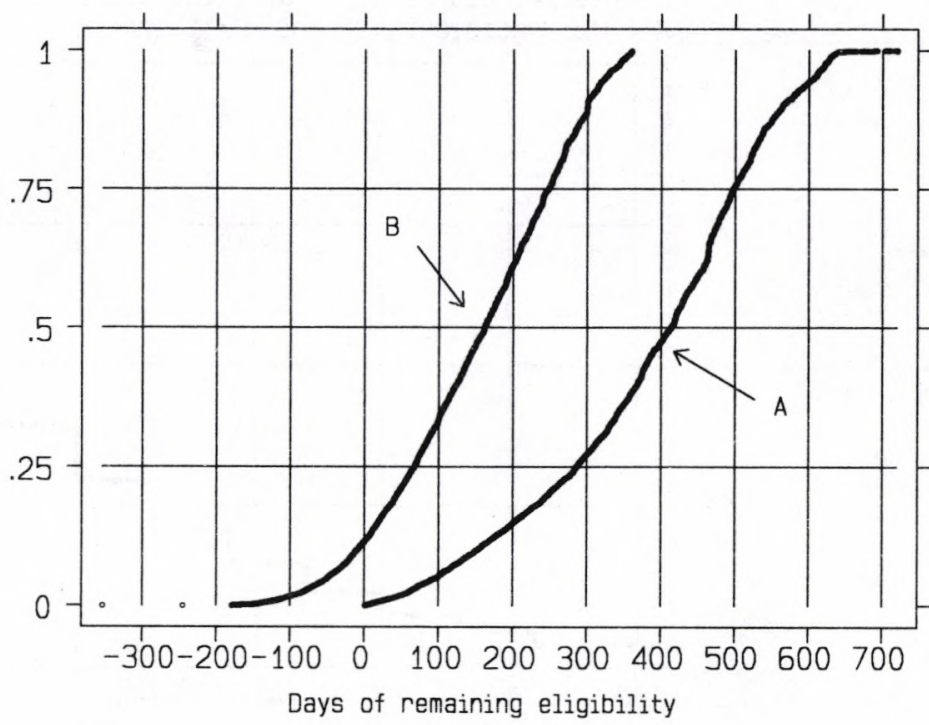

Distribution "A": actual situation on 20 March 1992

Distribution "B": situation on 20 March 1992 if 1993 rules applied 


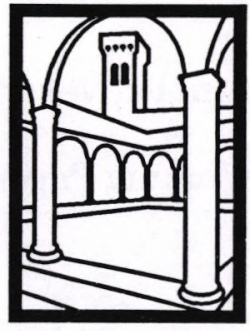

EUI

WORKING

PAPERS

EUI Working Papers are published and distributed by the European University Institute, Florence

Copies can be obtained free of charge

- depending on the availability of stocks - from:

The Publications Officer

European University Institute

Badia Fiesolana

I-50016 San Domenico di Fiesole (FI)

Italy 


\section{圈 \\ Publications of the European University Institute \\ Economics Department Working Paper Series}

To

Department of Economics WP

European University Institute

Badia Fiesolana

I-50016 San Domenico di Fiesole (FI)

Italy

From

Name

Address.

(Please print)

$\square$ Please enter/confirm my name on EUI Economics Dept. Mailing List

$\square$ Please send me a complete list of EUI Working Papers

$\square$ Please send me a complete list of EUI book publications

$\square$ Please send me the EUI brochure Academic Year 1994/95

Please send me the following EUI ECO Working Paper(s):

No, Author

Title:

No, Author

Title:

No, Author

Title:

No, Author

Title:

Date

Signature 


\section{Working Papers of the Department of Economics Published since 1993}

ECO No. 93/1

Carlo GRILLENZONI

Forecasting Unstable and Non-Stationary

Time Series

ECO No. 93/2

Carlo GRILLENZONI

Multilinear Models for Nonlinear Time

Series

ECO No. 93/3

Ronald M. HARSTAD/Louis PHLIPS

Futures Market Contracting When You

Don't Know Who the Optimists Are

ECO No. 93/4

Alan KIRMAN/Louis PHLIPS

Empirical Studies of Product Markets

ECO No. $93 / 5$

Grayham E. MIZON

Empirical Analysis of Time Series:

Illustrations with Simulated Data

ECO No. 93/6

Tilman EHRBECK

Optimally Combining Individual

Forecasts From Panel Data

ECO NO. 93/7

Víctor GÓMEZ/Agustín MARAVALL Initializing the Kalman Filter with Incompletely Specified Initial Conditions

ECO No. 93/8

Frederic PALOMINO

Informed Speculation: Small Markets

Against Large Markets

ECO NO. 93/9

Stephen MARTIN

Beyond Prices Versus Quantities

ECO No. 93/10

José María LABEAGA/Angel LÓPEZ

A Flexible Demand System and VAT

Simulations from Spanish Microdata

ECO No. 93/11

Maozu LU/Grayham E. MIZON

The Encompassing Principle and

Specification Tests
ECO No. 93/12

Louis PHLIPS/Peter MØLLGAARD

Oil Stocks as a Squeeze Preventing

Mechanism: Is Self-Regulation Possible?

ECO No. 93/13

Pieter HASEKAMP

Disinflation Policy and Credibility: The

Role of Conventions

ECO No. 93/14

Louis PHLIPS

Price Leadership and Conscious

Parallelism: A Survey

ECO No. 93/15

Agustín MARAVALL

Short-Term Analysis of Macroeconomic

Time Series

ECO No. 93/16

Philip Hans FRANSES/Niels

HALDRUP

The Effects of Additive Outliers on Tests for Unit Roots and Cointegration

\section{ECO No. 93/17}

Fabio CANOVA/Jane MARRINAN

Predicting Excess Returns in Financial

Markets

ECO No. 93/18

Iñigo HERGUERA

Exchange Rate Fluctuations, Market

Structure and the Pass-through

Relationship

ECO No. 93/19

Agustín MARAVALL

Use and Misuse of Unobserved

Components in Economic Forecasting

ECO No. 93/20

Torben HOLVAD/Jens Leth

HOUGAARD

Measuring Technical Input Efficiency for Similar Production Units:

A Survey of the Non-Parametric

Approach 
ECO No. 93/21

Stephen MARTIN/Louis PHLIPS

Product Differentiation, Market Structure and Exchange Rate Passthrough

ECO No 93/22

F. CANOVA/M. FINN/A. R. PAGAN

Evaluating a Real Business Cycle Model

ECO No 93/23

Fabio CANOVA

Statistical Inference in Calibrated Models

ECO No 93/24

Gilles TEYSSIÈRE

Matching Processes in the Labour Market in Marseilles. An Econometric Study

ECO No 93/25

Fabio CANOVA

Sources and Propagation of International

Business Cycles: Common Shocks or

Transmission?

ECO No. 93/26

Marco BECHT/Carlos RAMÍREZ

Financial Capitalism in Pre-World War I

Germany: The Role of the Universal

Banks in the Financing of German

Mining Companies 1906-1912

ECO No. 93/27

Isabelle MARET

Two Parametric Models of Demand,

Structure of Market Demand from

Heterogeneity

ECO No. 93/28

Stephen MARTIN

Vertical Product Differentiation, Intra-

industry Trade, and Infant Industry

Protection

ECO No. 93/29

J. Humberto LOPEZ

Testing for Unit Roots with the k-th

Autocorrelation Coefficient

ECO No. 93/30

Paola VALBONESI

Modelling Interactions Between State and

Private Sector in a "Previously" Centrally

Planned Economy
ECO No. 93/31

Enrique ALBEROLA ILA/J. Humberto LOPEZ/Vicente ORTS RIOS

An Application of the Kalman Filter to the Spanish Experience in a Target Zone (1989-92)

ECO No. 93/32

Fabio CANOVA/Morten O. RAVN

International Consumption Risk Sharing

ECO No. 93/33

Morten Overgaard RAVN

International Business Cycles: How much can Standard Theory Account for?

ECO No. 93/34

Agustín MARAVALL

Unobserved Components in Economic

Time Series

ECO No. 93/35

Sheila MARNIE/John

MICKLEWRIGHT

"Poverty in Pre-Reform Uzbekistan:

What do Official Data Really Reveal?"

ECO No. 93/36

Torben HOLVAD/Jens Leth

HOUGAARD

Measuring Technical Input Efficiency for

Similar Production Units:

80 Danish Hospitals

ECO No. 93/37

Grayham E. MIZON

A Simple Message for Autocorrelation

Correctors: DON'T

ECO No. 93/38

Barbara BOEHNLEIN

The Impact of Product Differentiation on

Collusive Equilibria and Multimarket

Contact

ECO No. 93/39

H. Peter MØLLGAARD

Bargaining and Efficiency in a

Speculative Forward Market

米米 
ECO No. 94/1

Robert WALDMANN

Cooperatives With Privately Optimal

Price Indexed Debt Increase Membership

When Demand Increases

ECO No. 94/2

Tilman EHRBECK/Robert

WALDMANN

Can Forecasters' Motives Explain

Rejection of the Rational Expectations

Hypothesis?

ECO No. 94/3

Alessandra PELLONI

Public Policy in a Two Sector Model of

Endogenous Growth

ECO No. 94/4

David F. HENDRY

On the Interactions of Unit Roots and

Exogeneity

ECO No. 94/5

Bernadette GOVAERTS/David F. HENDRY/Jean-François RICHARD

Encompassing in Stationary Linear

Dynamic Models

ECO No. 94/6

Luigi ERMINI/Dongkoo CHANG

Testing the Joint Hypothesis of Rationality and Neutrality under Seasonal Cointegration: The Case of Korea

ECO No. 94/7

Gabriele FIORENTINI/Agustín

MARAVALL

Unobserved Components in ARCH

Models: An Application to Seasonal

Adjustment

ECO No. 94/8

Niels HALDRUP/Mark SALMON

Polynomially Cointegrated Systems and their Representations: A Synthesis

ECO No. 94/9

Mariusz TAMBORSKI

Currency Option Pricing with Stochastic Interest Rates and Transaction Costs:

A Theoretical Model

ECO No. 94/10

Mariusz TAMBORSKI

Are Standard Deviations Implied in

Currency Option Prices Good Predictors

of Future Exchange Rate Volatility?
ECO No. 94/11

John MICKLEWRIGHT/Gyula NAGY

How Does the Hungarian Unemploy-

ment Insurance System Really Work? 


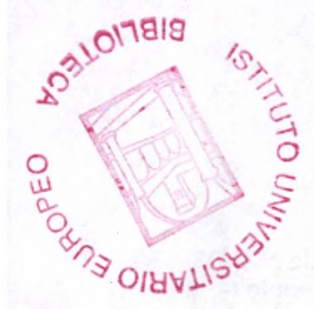

